\title{
EFFECT OF TWO DISTRACTION TECHNIQUES ON CHILDREN'S BEHAVIOUR, ANXIETY AND PAIN IN THE DENTAL SETTING
}

\author{
Aya Naguib Abd El Haleem*, Nagwa Mohammad Ali Khattab ${ }^{* *}$ \\ and Ahmad Abdel Hamid ELheeny ${ }^{* * *}$
}

\begin{abstract}
Aim: The aim of the current study was to evaluate the influence of using virtual reality (VR) eyeglasses on anxiety and pain perception during pulp therapy treatment in pediatric patients.

Methodology: 60 children, aged 4-6 years who were planned to receive vital pulp therapy (pulpotomy) in the mandibular primary molars were randomly divided into two equal groups (30 child per group); an experimental group (non-pharmacological behavior management and VR were used) and a control group (non-pharmacological behavior management was used). The behavior and anxiety of each child were recorded during dental examination, during and after treatment using Frankl behavior rating scale and Venham picture test respectively. Pain perception was recorded using Wong Baker's face pain scale at end of treatment.
\end{abstract}

Results: There were a significant improvement in the child behavior, pain perception and anxiety score $(\mathrm{p}<0.05)$ with use of VR eyeglasses during dental treatment.

Conclusion: Results of the current study demonstrated that VR eyeglasses could successfully decrease pain perception, anxiety and improve behavior during dental treatment.

KEYWORD: Dental, Child, Anxiety, Pain, Behavior, Distraction, Virtual reality.

\section{INTRODUCTION}

Most pediatric patients are fearful and apprehensive on their first visit to the dentist because of the dental equipment and the new experience (Kaur et al., 2015). While, anxiety is defined as uncomfortable feelings and sensations that is linked to actual or potential trauma to tissues (Lin et al., 2017), dental anxiety is described as "distressed expectation of dental visit to the degree that child can refuse treatment (Seligman et al., 2016).

In addition, pain management during dental procedures is critical for effective behavior guidance

\footnotetext{
* Faculty of Dentistry Minya University.

** Professor, Paediatric and Community Dentistry, Faculty of Dentistry, Ain Shams university, Cairo,Egypt

*** Associate Professor, Paediatric and Community Dentistry, Minia University, Minya, Egypt
} 
as the child's first dental experience is critical in shaping his or her attitude toward dentistry (Vishwakarma et al., 2017). Preventing pain will improve the dentist-patient relationship, create confidence, reduce fear and anxiety, and improve positive dental attitudes for future visits (Talo et al., 2017).

In general, child behavior during dental visits can be managed through non-pharmacological or pharmacological approaches according to situation. Distraction is considered as one of well-used behavioral modification techniques during children dental visits (Anthonappa et al., 2017). Also, VR is considered as a feasible distractive technique for control of child anxiety, pain and behavior during dental visit (Atzori et al., 2018; Koticha et al., 2019).

Systematic review of Custodo et al., 2020; Cunningham et al., 2021 demonstrated the limited well-designed clinical trial in assessment of VR effectiveness in anxiety, pain and behavior control for children during dental visits, thus the current study was designed as a step in formation of evidence of VR effusiveness as distractive approach during dental visit.

\section{PATIENTS AND METHODS}

\section{Ethical approval}

The current study was approved by ethics committee of Faculty of Dentistry, Minia University (approval number 284) and performed in compliance with Helsinki declaration and international conference on harmonization guidelines for good clinical practice. All parents / guardians of the eligible children assigned an informed consent after through explanation of the study experiment while for those refused to participate; their children were managed according to routine protocol of institution.

\section{Randomization and allocation}

Sixty eligible children were randomly divided into two equal groups by independent investigator using block randomization through online databases for clinical trials at https://www.sealedenvelope. com/simple-randomiser/v1/lists. The allocation concealment was performed using folded printed letters that placed within an aluminum foil. The letter included the patient's identification code, name, time, date and the group number. The envelope opened at the time of treatment with an independent nurse. Children assigned into two groups of 30 participants per group as following:

- Group (1): Intervention group (Nonpharmacological management and VR).

- Group(2): Control group(Non-pharmacological management).

\section{Eligibility standards}

The inclusions criteria were set as following; 1. Children age of 4-6 years old, 2.No previous dental experience involving local anesthesia (LA) administration, 3. Healthy children classified as class I or II according to ASA scale, and 4. Presence of mandibular primary molars indicated for vital pulp therapy. While exclusion criteria included; A. Patient with emotional or behavioral problems, B.Children with score more than or equal 25 on the screen child anxiety related disorders scale (SCARED), and C.Those with visual and/or auditory impairment.

\section{Clinical steps}

The procedures were conducted on two successive sessions by the same pediatric dentist with at least 5 years of experience; in first session: The parents were requested to fill out SCARED questionnaire parent version (Table 1).it is a 41 item inventory rated on a 3 point likert- type scale. The purpose of this instrument is to screen for signs of anxiety disorders in children. After the examination, 
a treatment plan was determined and discussed with the parent Iguardian then the child was introduced to the dental procedures using psychological behavior management techniques particularly tell-show-do technique (TSD).

While during the second session, LA, pulptomy procedure and stainless steel crowns (SSCs) were performed. Children in the experimental group showed the VR eyeglasses before beginning of the treatment and explained about their working. One of the popular cartoon series ('Tom and Jerry, Batman or Sponge Bob) started according to the child preference and the volume of audio adjusted to allow the child to listen instructions from the operator. Then inferior alveolar nerve block administered followed by a primary mandibular molar pulp therapy. The behavior of each child recorded during dental examination and after finishing of pulpotomy procedures using the Frankl behavior rating scale (FBRS).

To evaluate the child anxiety the video stopped at the following 4 occasions; 1.after dental examination, 2.after administration of LA, 3.after finishing pulpotomy procedures, and 4.after finishing placement of SSCs and at each time the child anxiety was measured using Venham Picture Scale. At the end of the treatment, the child was asked to register self- reported pain during treatment using Wong Baker Scale. For the control group the same procedures were done without the use of VR eyeglasses.

TABLE (1): Screen for Child Anxiety Related Disorders (SCARED)

\begin{tabular}{|c|c|c|c|}
\hline & $\begin{array}{l}0 \text { Not True or } \\
\text { Hardly Ever True }\end{array}$ & $\begin{array}{l}1 \text { Somewhat True } \\
\text { or Sometimes True }\end{array}$ & $\begin{array}{l}2 \text { Very True or } \\
\text { Often True }\end{array}$ \\
\hline \multicolumn{4}{|l|}{$\begin{array}{l}\text { 1. When my child feels frightened, it is hard for } \\
\text { him/her to breathe }\end{array}$} \\
\hline \multicolumn{4}{|l|}{$\begin{array}{l}\text { 2. My child gets headaches when he/she is at } \\
\text { school. }\end{array}$} \\
\hline \multicolumn{4}{|l|}{$\begin{array}{l}\text { 3. My child doesn't like to be with people he/ } \\
\text { she doesn't know well }\end{array}$} \\
\hline \multicolumn{4}{|l|}{$\begin{array}{l}\text { 4. My child gets scared if he/she sleeps away } \\
\text { from home }\end{array}$} \\
\hline \multicolumn{4}{|l|}{$\begin{array}{l}\text { 5. My child worries about other people liking } \\
\text { him/her }\end{array}$} \\
\hline \multicolumn{4}{|l|}{$\begin{array}{l}\text { 6. When my child gets frightened, he/she feels } \\
\text { like passing out }\end{array}$} \\
\hline \multicolumn{4}{|l|}{ 7. My child is nervous. } \\
\hline \multicolumn{4}{|l|}{ 8. My child follows me wherever I go } \\
\hline \multicolumn{4}{|l|}{ 9. People tell me that my child looks nervous. } \\
\hline \multicolumn{4}{|l|}{$\begin{array}{l}\text { 10. My child feels nervous with people he/she } \\
\text { doesn't know well. }\end{array}$} \\
\hline 11. My child gets stomachaches at school. & & & \\
\hline
\end{tabular}




\begin{tabular}{|c|c|c|c|}
\hline & $\begin{array}{c}0 \text { Not True or } \\
\text { Hardly Ever True }\end{array}$ & $\begin{array}{l}1 \text { Somewhat True } \\
\text { or Sometimes True }\end{array}$ & $\begin{array}{l}2 \text { Very True or } \\
\text { Often True }\end{array}$ \\
\hline \multicolumn{4}{|l|}{$\begin{array}{l}\text { 12. When my child gets frightened, he/she } \\
\text { feels like he/she is going crazy. }\end{array}$} \\
\hline \multicolumn{4}{|l|}{ 13. My child worries about sleeping alone } \\
\hline \multicolumn{4}{|l|}{$\begin{array}{l}\text { 14. My child worries about being as good as } \\
\text { other kids }\end{array}$} \\
\hline \multicolumn{4}{|l|}{$\begin{array}{l}\text { 15. When my child gets frightened, he/she } \\
\text { feels like things are not real. }\end{array}$} \\
\hline \multicolumn{4}{|l|}{$\begin{array}{l}\text { 16. My child has nightmares about something } \\
\text { bad happening to his/her parents }\end{array}$} \\
\hline \multicolumn{4}{|l|}{ 17. My child worries about going to school } \\
\hline \multicolumn{4}{|l|}{$\begin{array}{l}\text { 18. When my child gets frightened, his/her } \\
\text { heart beats fast }\end{array}$} \\
\hline \multicolumn{4}{|l|}{ 19. He/she gets shaky } \\
\hline \multicolumn{4}{|l|}{$\begin{array}{l}\text { 20. My child has nightmares about something } \\
\text { bad happening to him/her }\end{array}$} \\
\hline \multicolumn{4}{|l|}{$\begin{array}{l}\text { 21. My child worries about things working out } \\
\text { for him/her }\end{array}$} \\
\hline \multicolumn{4}{|l|}{$\begin{array}{l}\text { 22. When my child gets frightened, he/she } \\
\text { sweats a lot }\end{array}$} \\
\hline \multicolumn{4}{|l|}{ 23. My child is a worrier. } \\
\hline \multicolumn{4}{|l|}{$\begin{array}{l}\text { 24. My child gets really frightened for no } \\
\text { reason at all. }\end{array}$} \\
\hline \multicolumn{4}{|l|}{ 25. My child is afraid to be alone in the house } \\
\hline \multicolumn{4}{|l|}{$\begin{array}{l}\text { 26. It is hard for my child to talk with people } \\
\text { he/she doesn't know well }\end{array}$} \\
\hline \multicolumn{4}{|l|}{$\begin{array}{l}\text { 27. When my child gets frightened, he/she } \\
\text { feels like he/she is choking }\end{array}$} \\
\hline \multicolumn{4}{|l|}{$\begin{array}{l}\text { 28. People tell me that my child worries too } \\
\text { much. }\end{array}$} \\
\hline \multicolumn{4}{|l|}{$\begin{array}{l}\text { 29. My child doesn't like to be away from his/ } \\
\text { her family }\end{array}$} \\
\hline \multicolumn{4}{|l|}{$\begin{array}{l}\text { 30. My child is afraid of having anxiety (or } \\
\text { panic) attacks }\end{array}$} \\
\hline \multicolumn{4}{|l|}{$\begin{array}{l}\text { 31. My child worries that something bad might } \\
\text { happen to his/her parents. }\end{array}$} \\
\hline $\begin{array}{l}\text { 32. My child feels shy with people he/she } \\
\text { doesn't know well }\end{array}$ & & & \\
\hline
\end{tabular}




\begin{tabular}{|c|c|c|c|}
\hline & $\begin{array}{l}0 \text { Not True or } \\
\text { Hardly Ever True }\end{array}$ & $\begin{array}{l}1 \text { Somewhat True } \\
\text { or Sometimes True }\end{array}$ & $\begin{array}{l}2 \text { Very True or } \\
\text { Often True }\end{array}$ \\
\hline \multicolumn{4}{|l|}{$\begin{array}{l}\text { 33. My child worries about what is going to } \\
\text { happen in the future. }\end{array}$} \\
\hline \multicolumn{4}{|l|}{$\begin{array}{l}\text { 34. When my child gets frightened, he/she } \\
\text { feels like throwing up. }\end{array}$} \\
\hline \multicolumn{4}{|l|}{$\begin{array}{l}\text { 35. My child worries about how well he/she } \\
\text { does things }\end{array}$} \\
\hline \multicolumn{4}{|l|}{ 36. My child is scared to go to school } \\
\hline \multicolumn{4}{|l|}{$\begin{array}{l}\text { 37. My child worries about things that have } \\
\text { already happened }\end{array}$} \\
\hline \multicolumn{4}{|l|}{$\begin{array}{l}\text { 38. When my child gets frightened, he/she } \\
\text { feels dizzy }\end{array}$} \\
\hline \multicolumn{4}{|l|}{$\begin{array}{l}\text { 39. My child feels nervous when he/she is with } \\
\text { other children or adults and he/she has to do } \\
\text { something while they watch him/her (for } \\
\text { example: read aloud, speak, play a game, } \\
\text { play a sport.) }\end{array}$} \\
\hline \multicolumn{4}{|l|}{$\begin{array}{l}\text { 40. My child feels nervous when he/she is } \\
\text { going to parties, dances, or any place where } \\
\text { there will be people that he/she doesn't } \\
\text { know well. }\end{array}$} \\
\hline 41. My child is shy & & & \\
\hline
\end{tabular}

\section{Scoring}

A total score of $\geq 25$ may indicate the presence of an Anxiety Disorder. Scores higher than 30 are more specific.

\section{Statistical Data Analysis}

Collected data were tabulated and analyzed using SPSS software package version 22.0. (Armonk, NY: IBM Corp). The following statistical tests used; Kolmogorov-Smirnov test (testing normal distribution of data), Fisher's Exact test and Chi-Squared test (used for categorical data of independent groups), McNemar's test (used for paired nominal data), and unpaired Student t-test (used for continuous data of two independent groups). The level of significance level was set to $\leq$ 0.05 and $95 \%$.

\section{RESULTS}

The average scores of dental anxieties among children treated with traditional distraction method were higher than their peers treated with AV method. However, the differences were statistically significant following administration of LA and after final restoration placement. After LA administration, the means scores of dental anxiety in the control and intervention groups were $5 \pm 2.13$ and $3.97 \pm 1.43$ [Mean difference of $0.47 ; 95 \%$ CI of $0.09 ; 1.97$ ] respectively. After SSC placement the Venham's Picture Scale average scores in the control and intervention groups were $4.33 \pm 2.01$ and $3 \pm 1.98$ [Mean difference of $0.52 ; 95 \%$ CI of $-2.36 ;-0.30$ ] respectively (Table 2).

Regarding the frequencies of FBRS at baseline: in the control group, half of children $(n=15)(50 \%)$ 
were rated as positive and negative while in the intervention group 19 children (63.3\%) showed signs of negative behavior. The difference was not statistically significant $(\mathrm{p}=0.44)$. After finishing the procedure, the findings showed a statistically significant improvement in the frequency of children with positive behavior in the intervention group $(\mathrm{p}$ $=0.04)$. The signs of positive behavior reported in 21 children $(70 \%)$ in the intervention group. While in the control group the number of children with positive behavior were lower than that reported before beginning the treatment $(n=13)(43.3 \%)$ (Table 3).

The pain average score in the traditional distraction $(6.27 \pm 2.72)$ group was higher than that in the AV group $(5 \pm 1.88)$. This difference between the two groups was statistically significant $(\mathrm{p}=$ $0.04)$. The mean difference between the two groups was 1.25 with $95 \%$ CI of $(0.06 ; 2.49)$ (Table 4$)$.

TABLE (2): Mean of Venham Picture Scale of the control and intervention groups

\begin{tabular}{lcccccc}
\hline & \multicolumn{2}{c}{ Mean \pm SD } & Mean & SE & $\begin{array}{c}\text { p* } \\
\text { difference }\end{array}$ & $\begin{array}{c}\mathbf{9 5 \%} \text { CI } \\
\text { of mean } \\
\text { difference }\end{array}$ \\
\cline { 2 - 5 } Control group & Intervention group & & 0.9 & 0.51 & 0.08 & $-0.12 ; 1.92$ \\
\hline Baselines & $4.30 \pm 2.28$ & $3.40 \pm 1.63$ & 1.03 & 0.47 & $\mathbf{0 . 0 3}$ & $0.09 ; 1.97$ \\
\hline After LA & $5 \pm 2.13$ & $3.97 \pm 1.43$ & 0.33 & 0.42 & 0.43 & $-0.50 ; 1.17$ \\
\hline After pulpotomy & $5.23 \pm 1.91$ & $4.90 \pm 1.27$ & 1.33 & 0.52 & $\mathbf{0 . 0 1}$ & $-2.36 ;-0.30$ \\
\hline
\end{tabular}

${ }^{*}$ Student t-test, Level of significance set to $\leq 0.05$

TABLE (3): Frequency distribution of Frankl Behaviour Rating Scales at the baselines and at end of tretment in the intervention and control groups

\begin{tabular}{ccccc}
\hline FBRS & Reporting time & Control group N(\%) & Intervention group N(\%) & p* \\
\cline { 1 - 2 } Negative & Baseline data & $15(50)$ & $19(63.3)$ & 0.44 \\
\cline { 1 - 3 } Positive & & & $15(50)$ & $11(36.7)$ \\
\cline { 3 - 4 } Negative & \multirow{2}{*}{ End data } & $17(56.7)$ & $9(30)$ & $\mathbf{0 . 0 4}$ \\
\cline { 1 - 3 } Positive & & & $13(43.3)$ & $21(70)$ \\
\hline
\end{tabular}

${ }^{*}$ Fisher's Exact test, Level of significance set to $\leq 0.05$

TABLE (4): Mean of Wong Baker Face Scales of the control and intervention groups

\begin{tabular}{ccccccc}
\hline WBFS & Control group & Intervention group & $\begin{array}{c}\text { Mean } \\
\text { Difference }\end{array}$ & SE & p* & $\begin{array}{c}\text { 95\% CI of mean } \\
\text { difference }\end{array}$ \\
\hline Mean \pm SD & $\mathbf{6 . 2 7} \pm 2.72$ & $5 \pm 1.88$ & 1.27 & 0.60 & 0.04 & $0.06 ; 2.49$ \\
\hline
\end{tabular}

${ }^{*}$ Student t-test, Level of significance set to $\leq 0.05$ 


\section{DISCUSSION}

Dental anxiety significantly predicts pain and child behavior during and after dental treatment that highlights the importance of its control for providing optimal treatment and positive dental attitudes (Lee et al., 2018). However, many studies reported audiovisual distraction as an effective method to control dental anxiety (Attar et al., 2015; Nuvvula et al., 2015; Panda et al., 2017), they were considered as low evidence due to their poor design and high risk of bias (Liu et al., 2019; Cunningham et al., 2021). The current study hypothesized that there were no difference between using non-pharmacological behavior management alone or with VR in anxiety, pain perception and behavior of pediatric dental patient.

In order to establish the highest causal associations and level of evidence through the present study, randomized controlled trial design was followed through the study (Zabor et al., 2020). Random allocation of subjects were performed to minimize allocation bias thus providing similar chance of each participant to be included in each group and removing confounding by achieving groups that were similar in baseline characteristics (Sedgwick, 2015). Also allocation concealment was performed through using a printed letter which was covered with aluminum foil to hide the print and placed into opaque envelope thus minimize selection bias (Bespalov et al., 2019).

In addition, standardization was ensured through; definite eligibility criteria excluding any confounding factor that may affect accuracy of results as behavioral problems, anxiety disorders, visual and/or auditory impairment, and performance of same procedures and behavior management techniques by same investigator for all participants (Jeddy et al., 2018).

While SCARED questionnaire was used to evaluate the presence of childhood background anxiety disorders as being of long-term use with assured reliability excluding those with anxiety disorders background (Behrens et_al., 2019). In addition, Venham Picture Scale was selected to permit measurement of the state anxiety of children when visiting a dentist as being valid scale which is relatively easy to be administrated and is readily understood and accepted, by children (Oliveira et al., 2020). Also, the Frankl behavior rating scale was used which is one of the most reliable tool for behavior rating considered as the gold standard (Suresh et al., 2020)

The current study found that using virtual reality to distract children without anxiety problems during routine dental care decreased pain perception, reduced state anxiety, and improve patient behavior in agreement with previous studies of Attar et al., 2015; Nuvvula et al., 2015; Panda et al., 2017. These advantages may be related to more immersive images due to the occlusive headsets that project the images directly in front of the eyes of the user and block out real world (visual, auditory, or both) stimuli. The child's attention is focused on what is happening in the virtual world rather than on the real world (Atzori et al.2018)

The strength of this study is the well-designed randomized trial with appropriate sample size that can represent the whole population and add a remarkable step in building evidence of VR efficacy. The sole limitation of that study is lake of comparison with different audiovisual distractors.

\section{CONCLUSION}

Results of this study showed that VR eyewear could be successfully used to distract children during dental treatment. The VR can decrease the child anxiety, the amount of pain perceived in children, and help in improving patient cooperation. 


\section{REFERENCE}

- Anthonappa RP, Ashley PF, Bonetti DL, Lombardo G, Riley P. Non-pharmacological interventions for managing dental anxiety in children. Cochrane Database Syst Rev. 2017; (6): CD012676.

- Attar RH, Baghdadi ZD. Comparative efficacy of active and passive distraction during restorative treatment in children using an iPad versus audiovisual eyeglasses: a randomised controlled trial. Eur Arch Paediatr Dent. 2015;16(1):1-8.

- Atzori B, Lauro Grotto R, Giugni A, Calabrò M, Alhalabi W, Hoffman HG. Virtual Reality Analgesia for Pediatric Dental Patients. Front Psychol. 2018 Nov 23; 9:2265.

- Behrens B ,Swetlitz C, Pine DS, Pagliaccio D.() The Screen for Child Anxiety Related Emotional Disorders(SCARED): Informant Discrepancy, Measurement Invariance,and Test - Retest Reliability. Child psychiatry and human development J. 2019; 50(3):473-482

- Bespalov A, Wicke K,Castagne V. Blinding and Randomization. In:BespalovA,Michel M Steckler T. Good Research Practice in Pharmacology 2019: 257.

- Cunningham A, McPolin O, Fallis R. A systematic review of the use of virtual reality or dental smartphone applications as interventions for management of paediatric dental anxiety. BMC Oral Health 21, 244 (2021).

- Custodio NB, Costa F, Cademartori MG, Vanessa PP, Goettems ML. Effectiveness of virtual reality glasses as a distraction for children during dental care.Pediatric Dentistry, Volume 42, Number 2, March-April 2020, pp. 93-102(10)

- Jeddy N, Nithya S, Radhika T, Jeddy N. Dental anxiety and influencing factors: A cross-sectional questionnaire-based survey. Indian J Dent Res 2018;29:10-5.

- Kaur R, Jindal R, Dua R, Mahajan s, Sethi K, Garg S. Comparative evaluation of the effectiveness of audio and audiovisual distraction aids in the management of anxious pediatric dental patients. J Indian Soc Pedod Prev Dent $2015 ; 33(3): 192-203$

- Koticha P, Katge F, Shetty S, Patil DP. Effectiveness of Virtual Reality Eyeglasses as a Distraction Aid to Reduce Anxiety among 6-10-year-old Children Undergoing Dental Extraction Procedure. Int J Clin Pediatr Dent. 2019 JulAug;12(4):297-302

- Lee DW, Kim JG, Yang YM. The influence of parenting style on child behavior and dental anxiety, pediatr Dent.
2018; (40) : 327-333.

- $\quad$ Lin CS, Wu SY, Yi CA. Association between anxiety and pain in dental treatment: a systematic review and metaanalysis. J Dent Res. 2017; 96:153-162.

- $\quad$ Liu, Y., Gu, Z., Wang, Y., Wu, Q., Chen, V., Xu, X., \& Zhou, X. O. Effect of audiovisual distraction on the management of dental anxiety in children: a systematic review. IJPD. 2019; 29(1): 14-21.

- $\quad$ Suresh A, Karuna YM, Natarajan S, Maimoona TM, Shenoy S, Nayak AP, Rao AP, Shrikrishna SB. Assessing the behavior management problems during the first dental visit of preschool children using a doll placement test. J Indian Soc Pedod Prev Dent. 2020 Jan-Mar;38(1):41-47

- Nuvvula S, Alahari S, Kamatham R, Challa RR. Effect of audiovisual distraction with $3 \mathrm{D}$ video glasses on dental anxiety of children experiencing administration of local analgesia: a randomised clinical trial. Eur Arch Paediatr Dent. 2015;16(1):43-50.

- Oliveira MF, Stein CE, Schror FCL, Keske WR. Evaluation of child anxiety prior to dental care by means of Modified venham Picture Test, RMS Pictorial Scale and Facial Image Scale Tests. Pesqui Bras Odontopediatria Clin Integr. 2020; 20:e5068.

- Panda A. Effect of virtual reality distraction on pain perception during dental treatment in children.int $\mathrm{j}$ oral care Res.2017;5(4):278-81.

- Sedgwick P. controlled trials: allocation concealment, random allocation and blinding. BMJ. 2015; 350.h2633h2633.0.1136l=bmj.h2633 .

- Seligman LD, Hovey JD, Chacon K. Dental anxiety: an understudied problem in youth. Clin Psychol Rev. 2017; $55: 25-40$.

- Talo Yildirim T, Dundar S, Bozoglan A. Is there a relation between dental anxiety, fear and general psychological status? PeerJ. 2017;5:e2978

- Vishwakarma AP, Bondarde PA, Patil SB, Dodamani AS, Vishwakarma PY, Mujawar SA. Effectiveness of two different behavioral modification techniques among 5-7-yearold children: a randomized controlled trial. J Indian Soc Pedod Prev Dent 2017 Apr-Jun;35(2):143-149

- Zabor EC, Kaizer AM, Hobbs BP. (2020). Randomized Controlled Trials-chest journal volume 158, issue 1supplement S79-S87, JULY 01, 2020 